\title{
Competitive interaction between soybean cultivars and Sida rhombifolia
}

\author{
Alessandro Konzen ${ }^{1} \oplus$, Leandro Galon ${ }^{1 *} \oplus$, Sabrina Natalia Weirich ${ }^{1} \oplus$, Alessandra Gallina ${ }^{1} \oplus$, \\ Leonardo Brunetto ${ }^{1}$, Daiani Brandler ${ }^{2}$, Hugo von Linsingen Piazzetta ${ }^{1} \odot$, Ignácio Aspiazú ${ }^{3} \odot$ \\ ${ }^{1}$ Universidade Federal da Fronteira Sul, Erechim, RS, Brasil. E-mail: alessandrokonzen@gmail.com; leandro.galone@gmail.com; weirichsabrina@hotmail.com; \\ alessandragallina@hotmail.com; leonardobrunetto@outlook.com; hugo.piazzetta@uffs.edu.br \\ 2 Universidade Tecnológica Federal do Paraná, Pato Branco, PR, Brasil. E-mail: daianibrandler@hotmail.com \\ ${ }^{3}$ Universidade Estadual de Montes Claros, Janaúba, MG, Brasil. E-mail: ignacio.aspiazu@unimontes.br
}

ABSTRACT: The arrow-leaf sida (Sida rhombifolia), in addition to competing with soybeans, which causes productivity losses, is also host to the whitefly, which transmits viruses. The aim was to evaluate the competitive ability of soybean cultivars in the presence of an arrow-leaf sida biotype, with different proportions of plants in the association. The experiments were conducted in a completely randomized design, with four replications. Tested competitors included arrow-leaf sida with the four soybean cultivars in proportions crop:weed of 100:0; 75:25; 50:50; 25:75; and 0:100. Competitiveness analysis was carried out using diagrams applied to replacement series experiments in addition to the relative competitiveness indices. At 50 days after the emergence of the species, the variables height, diameter, leaf area, and dry mass of shoots were evaluated. Competition occurred between soybean cultivars in the presence of arrow-leaf sida, regardless of the plant proportion, causing reductions in all variables evaluated. Interspecific competition causes greater damage to al variables studied than intraspecific competition. There was competition for the same resources between soybean and arrow-leaf sida.

Key words: arrow-leaf sida; competitive ability; Glycine max L.

\section{Interação competitiva entre cultivares de soja e Sida rhombifolia}

RESUMO: A guanxuma (Sida rhombifolia), além de competir com a soja pelos recursos do meio causando redução da produtividade, é hospedeira da mosca branca, que transmite viroses. Objetivou-se avaliar a habilidade competitiva de cultivares de soja na presença de um biótipo de guanxuma, em diferentes proporções de plantas na associação. Os experimentos foram conduzidos em delineamento experimental completamente casualizado, com quatro repetições. Os competidores testados incluíram a guanxuma e quatro cultivares de soja nas proporções de 100:0; 75:25; 50:50; 25:75 e 0:100 cultura: planta daninha. Efetuou-se a analise da competitividade por diagramas aplicados a experimentos substitutivos, mais os indices de competitividade relativas. Aos 50 dias após a emergência das espécies, avaliou-se as variáveis altura, diâmetro de caule, área foliar e massa seca da parte aérea das plantas. Ocorreu competição entre as cultivares de soja na presença de guanxuma, independentemente da proporção de plantas, provocando reduções nas variáveis avaliadas. A competição interespecífica causa maiores prejuízos a todas as váriaveis estudadas do que a intraespecífica. Houve competição pelos mesmos recursos do meio entre a soja e a guanxuma.

Palavras-chave: guanxuma; habilidade competitiva; Glycine max L.

\footnotetext{
* Leandro Galon - E-mail: leandro.galone@gmail.com (Corresponding author)

Associate Editor: Mário de Andrade Lira Júnior
} 


\section{Introduction}

Soybean is an oil seed of great economic importance, used in animal and human food, as well as biodiesel manufacturing. It has become one of the most expressive crops in Brazil, which produces 123 million tons over 36.9 million hectares to become the single largest soybean producer, followed by the United States and Argentina (USDA, 2020).

The agronomic performance of soybean, as well as its grain yield and quality, can be affected by several factors, among them competition with weeds. Many weed species, such as wild poinsettia, beggarticks, crabgrass, alexandergrass, tropical sipderwort, morning glory, joint-vetch and others, compete with crops for water, light, and nutrients. In addition, some can release allelopathic substances, as well as host insects and diseases, which result in great losses (Piccinini et al., 2016; Forte et al., 2017; Ruchel et al., 2019).

Plants of the genus Sida have more than 170 species and are known by Brazilian farmers as "guanxumas". These plants frequently occur in pasture areas, by roadsides, in vegetable gardens, and near corrals and are currently distributed in most Brazilian agricultural areas, especially in no-till areas. Arrow-leaf sida (Sidar hombifolia) has high regrowth capacity when mechanical control is performed, and, when herbicides are applied, a good leaf area index is necessary for chemical control to have a positive effect. This species shows C3 metabolismand tolerates soils with a certain degree of compaction and environments with lower light intensity and temperature, thus leading it to be compared to a C4 plant (Constantin et al., 2007). This weed is difficult to control, as it has a deep root system, and is very competitive with soybean, especially due to its characteristic adaptability in poor and acidicsoils (Cunha et al., 2012; Heap, 2014).

Correct management of arrow-leaf sida is fundamental in soybean crops because its occurrence causes direct losses, decreasing grain yield, and indirect losses, hosting the whitefly (Bemisia tabaci), which transmits viruses to various crops (Rizzardi et al., 2003). For the development of weed control strategies in agricultural crops, prior knowledge of their characteristics is necessary. Therefore, the determination of competitive interactions between crops and weeds requires experimental designs and appropriate analytical methods. One of the most used methods is the conventional replacement series, where different weed and crop densities are used, keeping them in coexistence for a certain period and later analyzing their characteristics (Bastiani et al., 2016; Frandoloso et al., 2019).

In these experiments with replacement series, data interpretation results in the measurement of competitiveness among species in relation to the response of the variable under study, which can be shoot dry mass production, tillering, height, leaf area, and soil cover index. However, the response is given by the variation in the proportion of associated plants in the plant community (Bianchi et al., 2006; Agostinetto et al., 2013).

In field conditions, plant density is generally constant; on the other hand, weed density varies according to environmental conditions and soil seed bank, which alters the degree of infestation (Bianchi et al., 2006; Agostinetto et al., 2013). Thus, in competition studies, it is important to analyze the influence of density and variation on the proportion of plants among species and the density at which they occur (Bianchi et al., 2006).

The superior competitiveness of one species over another is given by the greater capacity it presents to grow and develop, its initial growth speed, greater leaf area index, production of many tillers or branching, greater stature, and root volume, among other factors (Agostinetto et al., 2013). Arrow-leaf sida is considered strongly competitive with agricultural crops because it has a very deep root system and survives in inhospitable environments (Constantin et al., 2007), in addition to hindering mechanical harvesting in annual crops due to stem resistance. Due to the damages arrow-leaf sida causes to soybean, management practices are necessary by combining control actions in addition to identifying soybean cultivars that present better competitive ability in the presence of weeds (Rizzardi \& Silva, 2014).

Thus, it is important to study the variation in the proportion between weeds and soybean cultivars in order to develop management strategies to define the characteristics that confer a better competitive ability on crops (Fleck et al., 2008; Agostinetto et al., 2013).

The research hypothesis is that there are differences in competitive ability among soybean cultivars when they are competing with the arrow-leaf sida biotype. Therefore, the objective of this study was to evaluate the competitive ability of soybean cultivars in competition with arrow-leaf sida.

\section{Materials and Methods}

Nine experiments were conducted in a greenhouse in units consisted of plastic pots with a capacity of $8 \mathrm{dm}^{3}$, filled with Aluminium-Iron Humic Red Lactosoil (Embrapa, 2013). The soil was previously corrected and fertilized according to the technical recommendations for soybean crops (Rolas, 2016). The chemical and physical characteristics of the soil were as follows: soil $\mathrm{pH}=4.8 ; \mathrm{SOM}=35 \mathrm{~g} \mathrm{dm}^{-3} ; \mathrm{P}=4.0 \mathrm{mg} \mathrm{dm}{ }^{-3} ; \mathrm{K}=$ $117.0 \mathrm{mg} \mathrm{dm}^{-3} ; \mathrm{Al}^{3+}=0.6 \mathrm{cmol}_{\mathrm{c}} \mathrm{dm}^{-3} ; \mathrm{Ca}^{2+}=4.7 \mathrm{cmol}_{\mathrm{c}} \mathrm{dm}^{-3} ; \mathrm{Mg}^{2+}$ $=1.8 \mathrm{cmol}_{\mathrm{c}} \mathrm{dm}^{-3}$; effective cation exchange capacity $\left(\mathrm{CEC}_{(\mathrm{t})}\right)=$ $7.4 \mathrm{cmol}_{\mathrm{c}} \mathrm{dm}^{-3}$; total cation exchange capacity $\left(\mathrm{CEC}_{(\mathrm{T})}\right)=16.5$ $\mathrm{cmol}_{\mathrm{c}} \mathrm{dm}^{-3} ; \mathrm{H}+\mathrm{Al}=9.7 \mathrm{cmol}_{\mathrm{c}} \mathrm{dm}^{-3} ;$ sum of bases $(\mathrm{SB})=6.8$ $\mathrm{cmol}_{\mathrm{c}} \mathrm{dm}^{-3}$; base saturation $(\mathrm{V})=41 \%$; and clay $=600 \mathrm{~g} \mathrm{dm}^{-3}$.

The experiments were set in a randomized blocks design, with four replications. The tested competitors included four soybean cultivars: Brasmax Ativa, DM 5958 RSF IPRO, Brasmax Elite and Nidera 5445 IPRO, which competed with an arrowleaf sida biotype. Soybean cultivars were chosen on the basis of the genetic differences they present and because they are the most cultivated by producers in Rio Grande do Sul, with the following characteristics: a) Brasmax Ativa: short plants, determinate growth habit, medium cycle, maturation group 5.6, insect resistance and herbicide tolerance; b) DonMario 5958 RSF IPRO: indeterminate growth habit, medium cycle, 
maturation group 5.8, insect resistance, and herbicide tolerance; c) Brasmax Elite IPRO: indeterminate growth habit, early cycle, maturation group 5.5, insect resistance, and herbicide tolerance; and d) Nidera 5445 IPRO: indeterminate growth habit, early cycle, maturation group 5.4, insect resistance, and herbicide tolerance.

Preliminary experiments were carried out for soybean cultivars and the arrow-leaf sida biotype, in a monoculture system, aiming to determine the plant population in which the final production becomes constant. For this purpose, populations of $1,2,4,8,16,24,32,40,48,56$, and 64 plants pot $^{-1}$ were used (equivalent to $24,48,96,192,384,576,768$, $960,1152,1344$, and 1536 plants $\mathrm{m}^{-2}$ ). The final constant production obtained was 20 plants pot ${ }^{-1}$ for all tested cultivars and the arrow-leaf, which was equivalent to 481 plants $\mathrm{m}^{-2}$.

In the second stage, four experiments were installed in a replacement series to evaluate the competitiveness of soybean cultivars with arrow-leaf sida, in different combinations of cultivars and weed species, varying the relative proportions of plants $\operatorname{pot}^{-1}(20: 0 ; 15: 5 ; 10: 10 ; 5: 15$; and $0: 20$ or $100: 0 ; 75: 25$; $50: 50 ; 25: 75$; and $0: 100)$, fixing the total plant population (20 plants pot ${ }^{-1}$ ).

At 50 days after emergence, we determined plant height (cm) using a graduated ruler, from the base to the apex of the plant; stem diameter $(\mathrm{mm})$ of both crop andweed with a digital pachymeter at $1 \mathrm{~cm}$ above the soil; leaf area $\left(\mathrm{cm}^{2}\right.$ pot $\left.{ }^{-1}\right)$; and shoot dry mass ( $\mathrm{g} \mathrm{pot}^{-1}$ ) of all the plants. To determine leaf area (LA), a portable leaf area meter model Cl-203 BioScience was used, quantifying the LA in all plants in each treatment. To measure the dry mass, the plants were sectioned close to the soil, packed in paper bags, and placed in a forced air oven at $60 \pm 5$ o $C$, until the material reached a constant mass.

The data were analyzed using the method of graphical analysis of variation or relative productivity (Cousens, 1991; Bianchi et al., 2006). This procedure consists in the construction of a diagram based on relative (RP) and total relative (TRP) productivity or variation. When RP results in a straight line, it means that the ability of the species is equivalent. If RP results in a concave line, it indicates that there is impairment in the growth of one or both species. In contrast, if RP shows a convex line, there is a benefit in the growth of one or both species. When TRP is equal to 1 (straight line), competition for the same resources occurs; if it is higher than 1 (convex line), competition is avoided and if TRP is less than 1 (concave line), there is mutual loss (Cousens, 1991).

The relative competitiveness $(R C)$, relative grouping coefficient $(K)$, and aggressiveness coefficient $(A)$ indices were calculated for plant proportions of 50:50 (soybean versus arrow-leaf sida) or 10:10 plants pot $^{-1}$, according to the equations described by Cousens \& O'Neill (1993). RC represents the comparative growth of soybean cultivars (X) in relation to the competitor arrow-leaf sida $(\mathrm{Y}) ; \mathrm{K}$ indicates relative dominance of one species over another, and $A$ points out the most competitive species. Soybean cultivars $X$ are more competitive than arrow-leaf sidaY when $\mathrm{RC}>1, \mathrm{Kx}>$ $K y$, and $A>0$; on the other hand, arrow-leaf sida $Y$ is more competitive than soybean cultivars $\mathrm{X}$ when $\mathrm{RC}<1, \mathrm{Kx}<\mathrm{Ky}$, and $A<0$ (Bianchi et al., 2006). The joint analysis of these values indicates more precisely the competitiveness of the species involved in the community.

The statistical analysis of productivity or relative variation included the calculation of differences for RP values (DRP), obtained in the proportions $25 \%, 50 \%$, and $75 \%$, in relation to the values belonging to the hypothetical straight line in the respective proportions, which are $0.25,0.50$, and 0.75 for RP (Bianchi et al., 2006). The " $t$ " test was used to test for differencesin the DRP, TRP, RC, K, and A indices (Bianchi et al., 2006). To test for differences in DRP and $A$, the null hypothesis was that the rates were equal to zero $(\mathrm{Ho}=0)$; for TRP and $\mathrm{RC}$, the rates were equal to one $(\mathrm{Ho}=1)$; and for $\mathrm{K}$, the rates of the differences between $\mathrm{Kx}$ and $\mathrm{Ky}$ were equal to zero [ $\mathrm{Ho}=(\mathrm{Kx}$ $\mathrm{Ky})=0$ ]. The criterion to consider the TRP and RP curves as different from those expected, was when the expected values (represented by dotted lines) were outside the confidence interval of $95 \%$ of the observed curves - solid and colored lines with confidence intervals in the same color (Galon et al., 2015a; Concenço et al., 2018). The criterion used to consider the RP and TRP curves different from the hypothetical straight lines was that at least in two proportions of the tested densities of the competing species they did not touch the colored lines, adapted from Bianchi et al. (2006).

Results obtained for plant height, stem diameter, leaf area and shoot dry mass, expressed in mean values per treatment, were submitted to analysis of variance by the $F$ test and, when significant, the means were compared by Dunnett's test, considering the monocultures as the control. In all statistical analyses, $\mathrm{p} \leq 0.05$ was adopted.

\section{Results and Discussion}

The graphic results show, for the plant combinations of soybean cultivars Brasmax Ativa, DonMario 5958 RSF IPRO, Brasmax Elite and Nidera 5445 IPRO with arrow-leaf sida (competitor), that all cultivars perform similarly in competition with the weed, with significant differences in plant height, stem diameter, leaf area, and dry mass in the tested proportions, since the colored lines were different from the expected or dotted lines in at least two proportions (Figures 1-4).

Regarding TRP, there were significant differences between expected and estimated values of plant height, leaf area, and shoot dry mass of cultivars Brasmax Ativa, DonMario 5958 RSF IPRO, Brasmax Elite and Nidera 5445 IPRO, cultivated in at least two different proportions, when competing with arrowleaf sida, presenting concave lines and mean values below 1 (Figures 1, 3, and 4). These TRP results allow to conclude that there was competition between soybean and the weed. As reported by Rubin et al. (2014) when TRP is less than 1, there is mutual antagonism between species that are competing for environmental resources.

The TRP showed no difference for plant diameter in the studied proportions (Figure 2), with values close to 1 . This demonstrates that soybean cultivars and arrow-leaf 

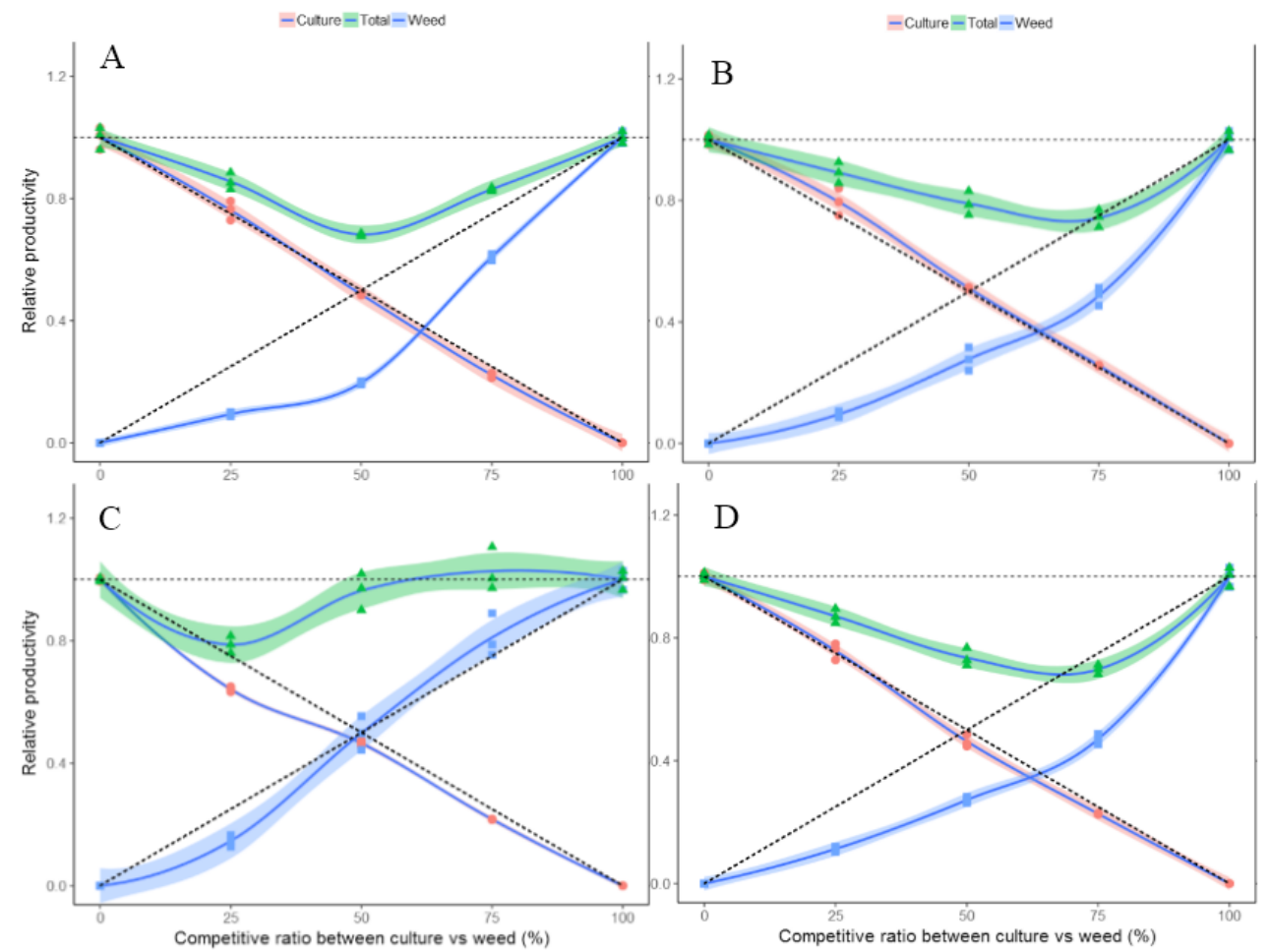

Figure 1. Relative productivity (RP) for plant height $(\mathrm{cm})$ of soybean cultivars $(\bullet)$ and arrow-leaf sida $(\mathbf{})$ : Brasmax Ativa (A), DonMario 5958 RSF IPRO (B), Brasmax Elite (C) and Nidera 5445 IPRO (D), and total relative productivity (TRP) of the community ( $\mathbf{\Lambda}$ ) according to the proportion of plants (soybean: arrow-leaf sida). Dotted lines represent the expected values in the absence of competition, in the solid lines the values observed when the species competed in different plant proportions and colored bands represent the standard deviation of the observations.
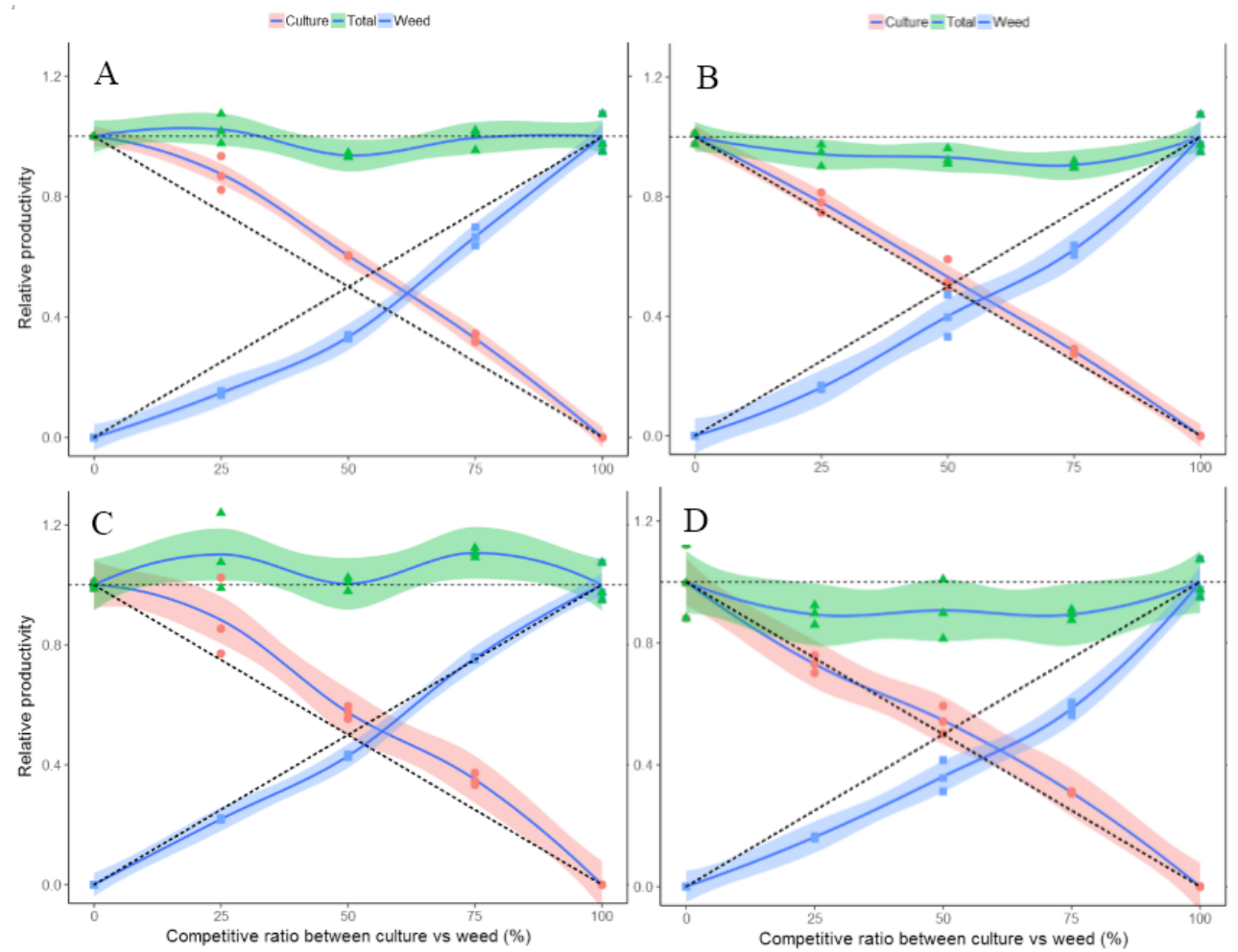

Figure 2. Relative productivity (RP) for stem diameter $(\mathrm{mm})$ of soybean cultivars $(\bullet)$ and arrow-leaf sida plants $(\mathbf{\square})$ : Brasmax Ativa (A), DonMario 5958 RSF IPRO (B), Brasmax Elite (C) and Nidera 5445 IPRO (D), and total relative productivity (TRP) of the community $(\mathbf{\Lambda})$ according to the proportion of plants (soybean: arrow-leaf sida). Dotted lines represent the expected values in the absence of competition, in the solid lines the values observed when the species competed in different plant proportions and colored bands represent the standard deviation of the observations. 
sida compete for the same environmental resources, which exist in limited quantities and are available for growth and development of both species. Fleck et al. (2008) also found no differences for TRP when irrigated rice competed with red rice, with values close to 1 .

Silva et al. (2014), evaluating soybeans competing with susceptible and resistant biotypes of Conyza bonariensis, observed that the TRP presented a concave line for plant height, indicating mutual damage to plant growth, while for leaf area, TRP showed no difference, and for dry mass there was only a difference in the susceptible biotype. Such results agree with the findings in this study.

The plant height of Brasmax Ativa, DonMario 5958 RSF IPRO and Nidera 5445 IPRO presented deviations of RP lines very close to the expected straights lines. This indicates less damage to the crop than to arrow-leaf sida, since the values presented by the weed were very far from the expected, presenting a concave line and a detrimental effect on stature (Figure 1). Franco et al. (2017), evaluating the relative competitiveness of goose grass biotypes infesting soybean, observed that plant height presented values similar to or below the hypothetical line, indicating that the competition did not cause damage to the crop.

Regarding stem diameter (Figure 2), crop results were close to those expected for RP and TRP. In an evaluation of competition between the crop and arrow-leaf sida in the proportion 50:50, ten soybean plants competing with ten arrow-leaf sida plants, the cultivars Brasmax Ativa,
DonMario 5958 RSF IPRO, Brasmax Elite and Nidera 5454 IPRO presented an increase of $20.56 ; 6.43 ; 14.71$, and $9.00 \%$, while the arrow-leaf sida presented a decrease of 33.12, $20.00,14.37$, and $27.50 \%$ when they competed against each other, respectively, that is, when the plant proportion of each cultivar competed against the same proportion of weeds. These results demonstrate that both species compete for the same environmental resources, but their competitive abilities are different; in this case, the crop was more competitive than the weed.

It was observed for leaf area and shoot dry mass, in all plant combinations involving the cultivars Brasmax Ativa, DonMario, Brasmax Elite, and Nidera 5445 with arrow-leaf sida, that the deviations of the RP lines in relation to the expected straight lines presented concave lines in all simulations. In addition, there was significance in at least two proportions of plants (Figures 3 and 4), for both crop and weed. This fact demonstrates that both compete for the same environmental resources where they are inserted, causing damage to their growth. Forte et al. (2017) evaluating the competition of soybean cultivars Brasmax Alvo RR and Fundacep 55RR with beggarticks and wild poinsettia also found concave lines for the crop and weeds, corroborating the findings of this study.

The soybean cultivars presented greater plant heights and stem diameters than arrow-leaf sida in general; in other words, the observed results were close to the expected values, and this fact indicates that competition occurs for environmental resources, such as etiolation in the search for
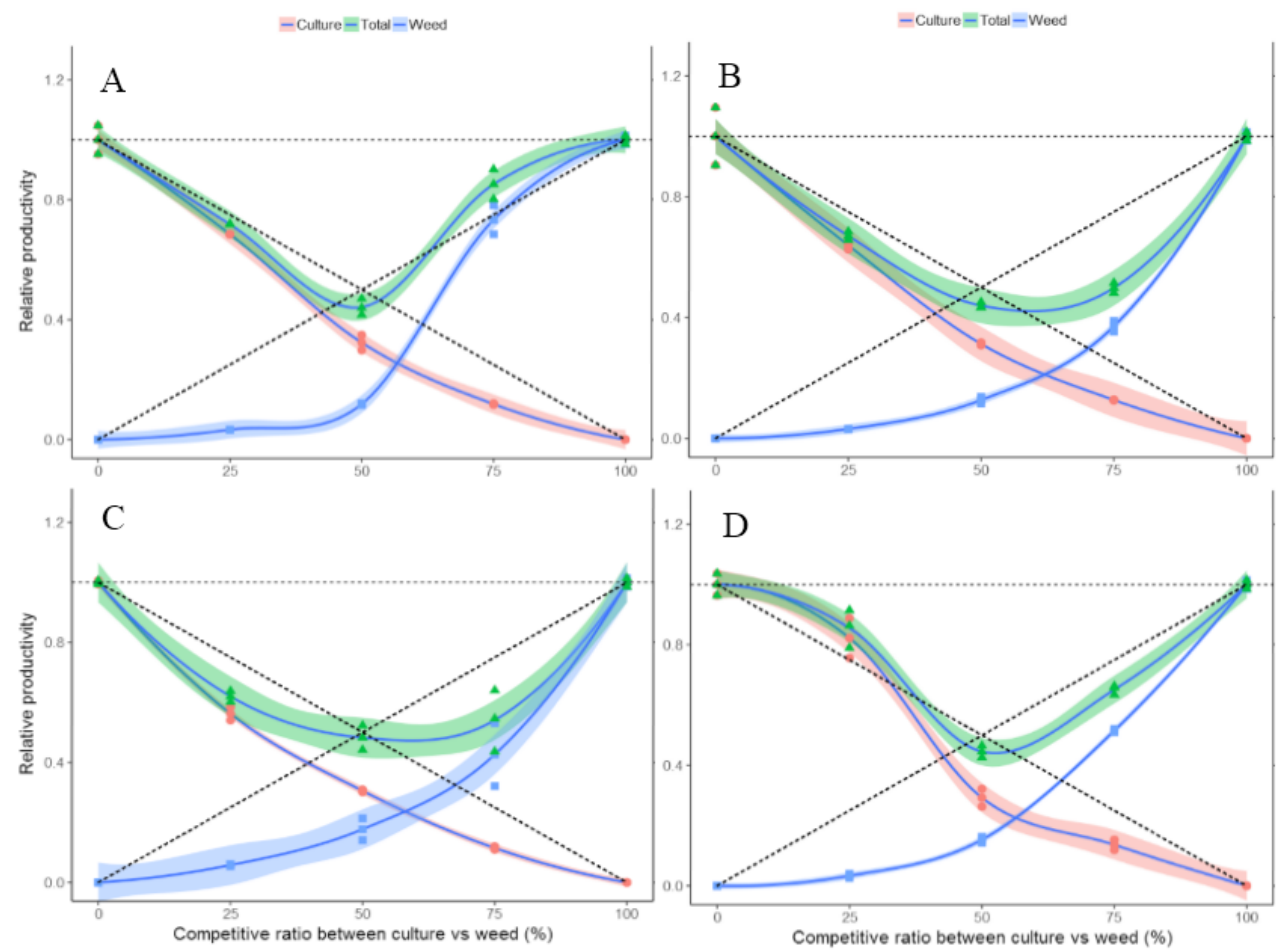

Figure 3. Relative productivity (RP) for leaf area $\left(\mathrm{cm}^{2}\right.$ pot $\left.^{-1}\right)$ of soybean cultivars $(\bullet)$ and arrow-leaf sida plants $(\boldsymbol{\square})$ : Brasmax Ativa (A), DonMario 5958 RSF IPRO (B), Brasmax Elite (C) and Nidera 5445 IPRO (D), and total relative productivity (TRP) of the community $(\boldsymbol{A})$ according to the proportion of plants (soybean: arrow-leaf sida). Dotted lines represent the expected values in the absence of competition, in the solid lines the values observed when the species competed in different plant proportions and colored bands represent the standard deviation of the observations. 

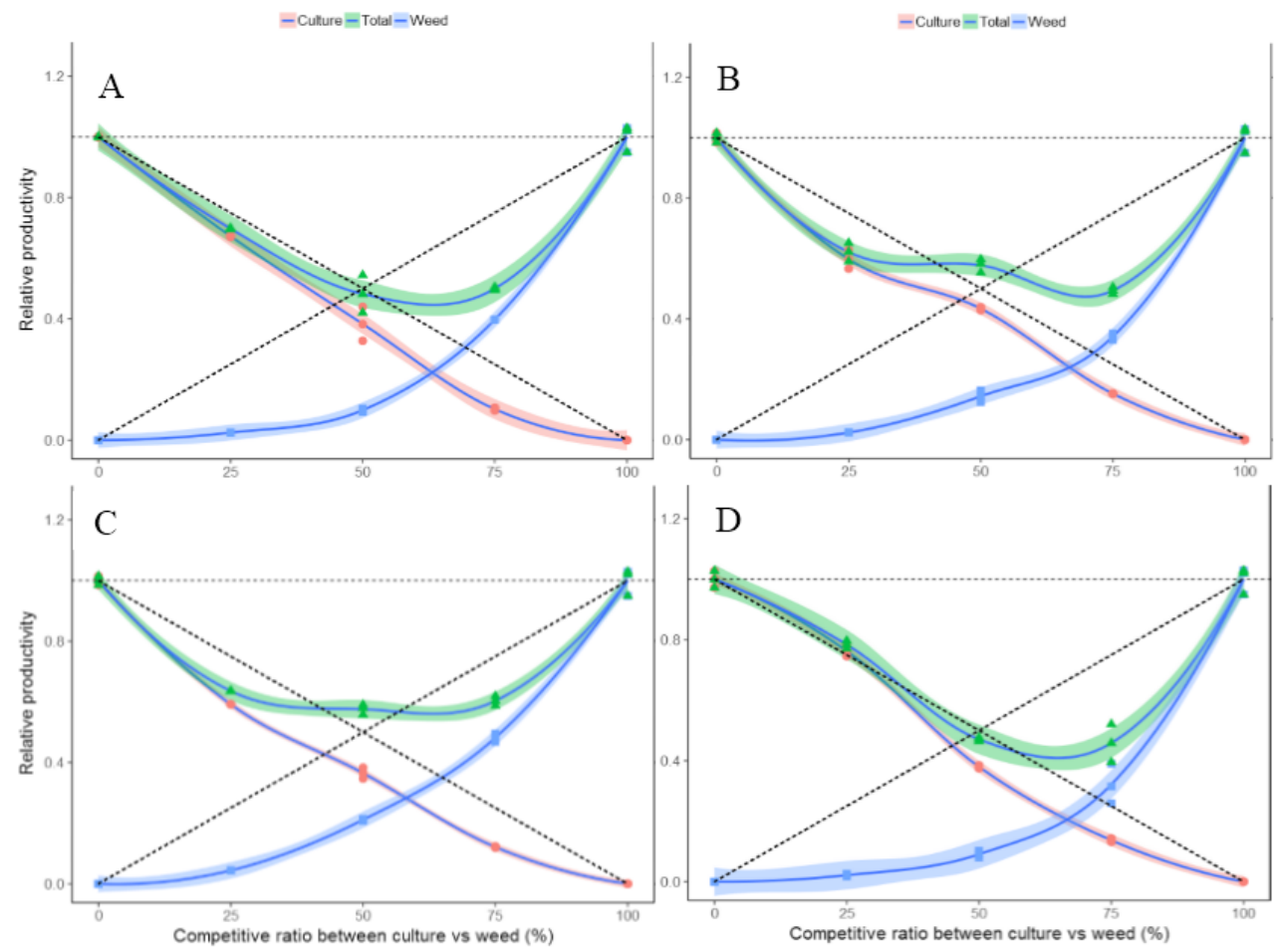

Figure 4. Relative productivity (RP) for dry mass $\left(\mathrm{cm}^{2}\right.$ pot $\left.^{-1}\right)$ of soybean cultivars $(\bullet)$ and arrow-leaf sida plants $(\mathbf{\square})$ : Brasmax Ativa (A), DonMario 5958 RSF IPRO (B), Brasmax Elite (C) and Nidera 5445 IPRO (D), and total relative productivity (TRP) of the community $(\mathbf{\Lambda})$ according to the proportion of plants (soybean: arrow-leaf sida). Dotted lines represent the expected values in the absence of competition, in the solid lines the values observed when the species competed in different plant proportions and colored bands represent the standard deviation of the observations.

light. This is proven by the fact that, for the variables leaf area and shoot dry mass, the crop did not present the same small deviation from expected values. In contrast, both crop and weed showed concave lines, which refers to damage to both species involved in competition.

In general, soybean cultivars showed higher relative growth than arrow-leaf sida for the variable's height, diameter, leaf area and shoot dry mass in all plant evaluated proportions, demonstrating a higher RP for the crop and a lower one for the weed; however, they had little contribution to TRP (Figures 1-4). Soybean has shown higher relative growth than arrow-leaf sida and has shown greater competitiveness; the probable reason may be related to the density of plants that competed with the crop, since weeds have greater competitive ability at high population densities than individually (Agostinetto et al., 2013; Forte et al., 2017). It should be emphasized that, in replacement series experiments, there is little evidence of qualitative changes due to increases in the density. In other words, the dominance of one species over another rarely changes when the density is modified (Cousens \& O'Neill, 1993).

The results show increases in TRP combinations as the proportion of plants competing against each other increased, a significant situation for all studied variables (Figures 1-4). This behavior shows that the species are competitive, and one of them does not contribute more than expected to the total productivity of the other. The two species belong to distinct botanical families, therefore, soybean cultivars and arrow-leaf sida would explore different ecological niches and would not compete for the same environmental resources. Thus, their competitiveness would not be distinct, because these differences were verified in many studies using related species, such as rice $x$ red rice (Fleck et al., 2008) and canola $x$ turnip (Galon et al., 2015b), and soybean $x$ hairy fleabane glyphosate-resistant and susceptible to glyphosate (Silva et al., 2014). However, some studies report the occurrence of differentiation in plant competition, even among different families, such as crabgrass $x$ soybean (Agostinetto et al., 2013) and soybean $\mathrm{x}$ beggarticks and wild poinsettia (Forte et al., 2017). Forte et al. (2017) when working with soybeans in competition with beggarticks and wild poinsettia, found that the community's TRP was also damaged, demonstrating that both weeds and soybeans present losses when competing.

The relative growth of soybean cultivars Brasmax Ativa, DM 5958 RSF IPRO, Brasmax Elite and Nidera 5445 IPRO presented, in general, similar values in the same proportion of plants in competition, for all variables (Figures 1-4). Thus, although the cultivars had distinct characteristics regarding height and development cycle, there were no differences when competing with arrow-leaf sida, i. e., all cultivars showed similar behavior in the presence of the weeds. These results allow to infer that the genetic characteristics of the soybean cultivars do not have a significant effect on arrow-leaf sida, and the competitive ability of soybean cultivars with the weed was equivalent.

Regarding the morphological variable's height, diameter, leaf area and shoot dry mass of soybean 
cultivars Brasmax Ativa, DonMario 5958 RSF IPRO, Brasmax Elite and Nidera 5445 IPRO, in general, they decreased when the cultivars competed with arrow-leaf sida in all associations analyzed, regardless of the plant proportion in the association (Table 1).
The greater the proportion of the competitor in the association, the greater the detrimental effects on soybean variables. Moreover, there was a decrease in morphological variables when arrow-leaf sida was present as an equal or lesser proportion of the plants, compared with the soybean

Table 1. Biometric responses of soybean cultivars (Glycine max) submitted to interference of the competitor arrow-leaf sida (Sida rhombifolia), expressed in plant height, stem diameter, leaf area and shoot dry mass, in an experiment conducted in replacement series, evaluation at 55 days after plant emergence

\begin{tabular}{|c|c|c|c|c|}
\hline \multirow[b]{2}{*}{$\begin{array}{c}\text { Proportion of plants } \\
\text { (soybean:arrow-leaf sida) }\end{array}$} & \multicolumn{4}{|c|}{ Variables } \\
\hline & $\begin{array}{l}\text { Plant height } \\
\text { (cm) }\end{array}$ & $\begin{array}{l}\text { Stem diameter } \\
(\mathrm{mm})\end{array}$ & $\begin{array}{l}\text { Leaf area } \\
\left(\mathrm{cm}^{2} \text { pot }^{-1}\right)\end{array}$ & $\begin{array}{l}\text { Dry mass } \\
\left(\text { g pot }^{-1}\right)\end{array}$ \\
\hline & \multicolumn{4}{|c|}{ Brasmax Ativa } \\
\hline $100: 0(T)$ & 33.73 & 2.48 & 4707.84 & 43.09 \\
\hline $75: 25$ & 34.27 & $2.89 *$ & $4300.68^{*}$ & 38.66 \\
\hline $50: 50$ & $32.80 *$ & $2.99 *$ & 3047.53* & $33.03^{*}$ \\
\hline $25: 75$ & $29.97 *$ & $3.25^{*}$ & $2233.34 *$ & $17.62^{*}$ \\
\hline \multirow[t]{2}{*}{ C.V (\%) } & 3.70 & 4.60 & 5.20 & 8.30 \\
\hline & \multicolumn{4}{|c|}{ Competitor arrow-leaf sida } \\
\hline $0: 100(T)$ & 17.83 & 1.60 & 574.83 & 6.02 \\
\hline $25: 75$ & $14.47 *$ & $1.42^{*}$ & 562.02 & $3.19 *$ \\
\hline $50: 50$ & $7.00^{*}$ & $1.07 *$ & $136.10^{*}$ & $1.19 *$ \\
\hline $75: 25$ & $6.70^{*}$ & $0.95^{*}$ & $76.27^{*}$ & $0.60^{*}$ \\
\hline \multirow[t]{2}{*}{ C.V (\%) } & 3.40 & 5.9 & 6.3 & 5.60 \\
\hline & \multicolumn{4}{|c|}{ DonMario 5958 RSF IPRO } \\
\hline $100: 0(T)$ & 35.37 & 3.11 & 6840.66 & 50.15 \\
\hline $75: 25$ & 37.50 & 3.24 & $5831.32 *$ & 39.96* \\
\hline $50: 50$ & 36.20 & 3.31 & $4280.99 *$ & $43.50^{*}$ \\
\hline $25: 75$ & 36.30 & $3.52^{*}$ & $3480.19 *$ & $30.60^{*}$ \\
\hline \multirow[t]{2}{*}{ C.V (\%) } & 3.4 & 6.4 & 7.3 & 3.1 \\
\hline & \multicolumn{4}{|c|}{ Competitor arrow-leaf sida } \\
\hline $0: 100(T)$ & 17.70 & 1.60 & 574.83 & 6.02 \\
\hline $25: 75$ & $11.47 *$ & $1.33^{*}$ & 284.39* & $2.74 *$ \\
\hline $50: 50$ & $9.83^{*}$ & $1.28^{*}$ & $145.92 *$ & $1.73^{*}$ \\
\hline $75: 25$ & $6.80^{*}$ & $1.03^{*}$ & 71.81* & $0.57^{*}$ \\
\hline \multirow[t]{2}{*}{ C.V (\%) } & 8.6 & 10.9 & 4.3 & 7.4 \\
\hline & \multicolumn{4}{|c|}{ Brasmax Elite } \\
\hline $100: 0(T)$ & 34.60 & 2.99 & 6936.50 & 52.78 \\
\hline $75: 25$ & $29.60 *$ & 3.52 & 5199.82* & $41.64 *$ \\
\hline $50: 50$ & $32.20^{*}$ & 3.43 & $4234.00^{*}$ & $38.52 *$ \\
\hline $25: 75$ & $30.00 *$ & $4.19 *$ & $3182.97^{*}$ & $25.59 *$ \\
\hline \multirow[t]{2}{*}{ C.V (\%) } & 1.4 & 9.3 & 3.0 & 3.0 \\
\hline & \multicolumn{4}{|c|}{ Competitor arrow-leaf sida } \\
\hline $0: 100(T)$ & 17.70 & 1.60 & 574.83 & 6.02 \\
\hline $25: 75$ & 19.13 & 1.61 & $326.53^{*}$ & $3.87^{*}$ \\
\hline $50: 50$ & 17.63 & $1.37^{*}$ & $203.71^{*}$ & $2.54^{*}$ \\
\hline $75: 25$ & 10.33* & $1.40^{*}$ & $132.65^{*}$ & $1.06 *$ \\
\hline \multirow[t]{2}{*}{ C.V (\%) } & 10.2 & 4.1 & 16.5 & 4.8 \\
\hline & \multicolumn{4}{|c|}{ Nidera 5445 IPRO } \\
\hline $100: 0(T)$ & 34.20 & 3.11 & 5804.43 & 46.71 \\
\hline $75: 25$ & 34.57 & 3.03 & 6366.20 & 47.51 \\
\hline $50: 50$ & $31.67 *$ & 3.39 & $3394.25^{*}$ & $35.48^{*}$ \\
\hline $25: 75$ & $31.07^{*}$ & $3.84^{*}$ & $3163.22^{*}$ & $25.61^{*}$ \\
\hline \multirow[t]{2}{*}{ C.V $(\%)$} & 3.2 & 8.2 & 9.1 & 3.0 \\
\hline & \multicolumn{4}{|c|}{ Competitor arrow-leaf sida } \\
\hline $0: 100(T)$ & 17.70 & 1.60 & 574.83 & 6.02 \\
\hline $25: 75$ & $11.10^{*}$ & $1.25 *$ & $395.07^{*}$ & $2.58^{*}$ \\
\hline $50: 50$ & 9.63* & $1.16^{*}$ & $176.12 *$ & $1.09 *$ \\
\hline $75: 25$ & $7.97^{*}$ & $1.04 *$ & $76.26^{*}$ & $0.52^{*}$ \\
\hline C.V (\%) & 4.7 & 9.0 & 4.1 & 13.4 \\
\hline
\end{tabular}

* Means differs from the control (T) by Dunnett's test $(p \leq 0.05)$. 
cultivars Brasmax Ativa, DonMario 5958 RSF IPRO, Brasmax Elite and Nidera 5445 IPRO (Table 1).

Studies show that crop and weed growth may be impaired when they are competing in a certain community (Fleck et al., 2008; Forte et al., 2017; Frandoloso et al., 2019). The lowest values of leaf area accumulation and shoot dry mass show high interspecific competition, in which the species compete for the same environmental resources, according to studies that evaluated the interference between turnip (Bianchi et al., 2006) and beggarticks or wild poinsettia (Forte et al., 2017) when infesting soybean cultivars. In the present work, the crop was uniformly distributed, which increases its competitive ability. Seed distribution in rows, as generally used in field conditions, increases the damages caused by the infesting community (Dusabumuremyi et al., 2014).

The results show, in general, for the variables height, diameter, leaf area and shoot dry mass, that the greatest means per plant of the crop or even of arrow-leaf sida were obtained when they were in lower densities in the associations in all combinations (Table 1). Forte et al. (2017) also verified that differentiation occurs in the competitive effect in species belonging to different botanical families (beggarticks Asteraceae and wild poinsettia - Euphorbiaceae) when they infest soybean fields (Fabaceae).

The values of height, diameter, leaf area and shoot dry mass of soybean cultivars in the proportions of each combination $(25 \%, 50 \%$, and $75 \%)$, in addition to those obtained in monoculture $(100 \%)$, show that interspecific competition involving the species in the association (soybean $\mathrm{x}$ arrow- leafsida) was more intense, with the highest means by crop and weed plants, when they were sown at greater densities (Table 1). The results of Bianchi et al. (2006), who evaluated soybean $x$ turnip and Forte et al. (2017), when researching soybean $x$ beggarticks and wild poinsettia, corroborate the findings of this study. Competition affects production quantitatively and qualitatively, as it modifies the efficient use of environmental resources, such as water, light, $\mathrm{CO}_{2}$, and nutrients (Bianchi et al., 2006), being established between the crop and other species existing on the same site. Plants which establish themselves first in a community benefit from the competition process or even due to different characteristics such as greater height, leaf area index, green or dry mass production, root system and others. These characteristics determine which cultivar shows greater competitive ability.

When sowing crops in association with weeds, using variation in the proportion of plants, crops usually have an advantage in relation to relative productivity, thus demonstrating that intraspecific competition exceeds interspecific competition (Bianchi et al., 2006). Similar results occurred when soybean was sown with crabgrass (Agostinetto et al., 2013) or beggarticks and wild poinsettia (Forte et al., 2017).

The growth of soybean cultivars Brasmax Ativa, DonMario 5958 RSF IPRO, Brasmax Elite and Nidera 5445 IPRO exceeded the growth of arrow-leaf sida, according to the RC index (greater than 1) for all studied variables (Table 2). Relative dominance of soybean over the weed expressed in the $K$ indices $\left(\mathrm{K}_{\text {soybean }}>\mathrm{K}_{\text {arrow-leaf sida }}\right)$ was also observed, and, according to the

Table 2. Competitiveness indices between soybean cultivars (Glycine max) and arrow-leaf sida (Sida rhombifolia), competing in equal proportions of plants (50:50), expressed by relative competitiveness (RC), coefficients of relative clusters (K) and aggressiveness (A), obtained in experiments conducted in replacement series, for the variables height of plants, stem diameter, leaf area and shoot dry mass at 55 days after emergence of the plants.

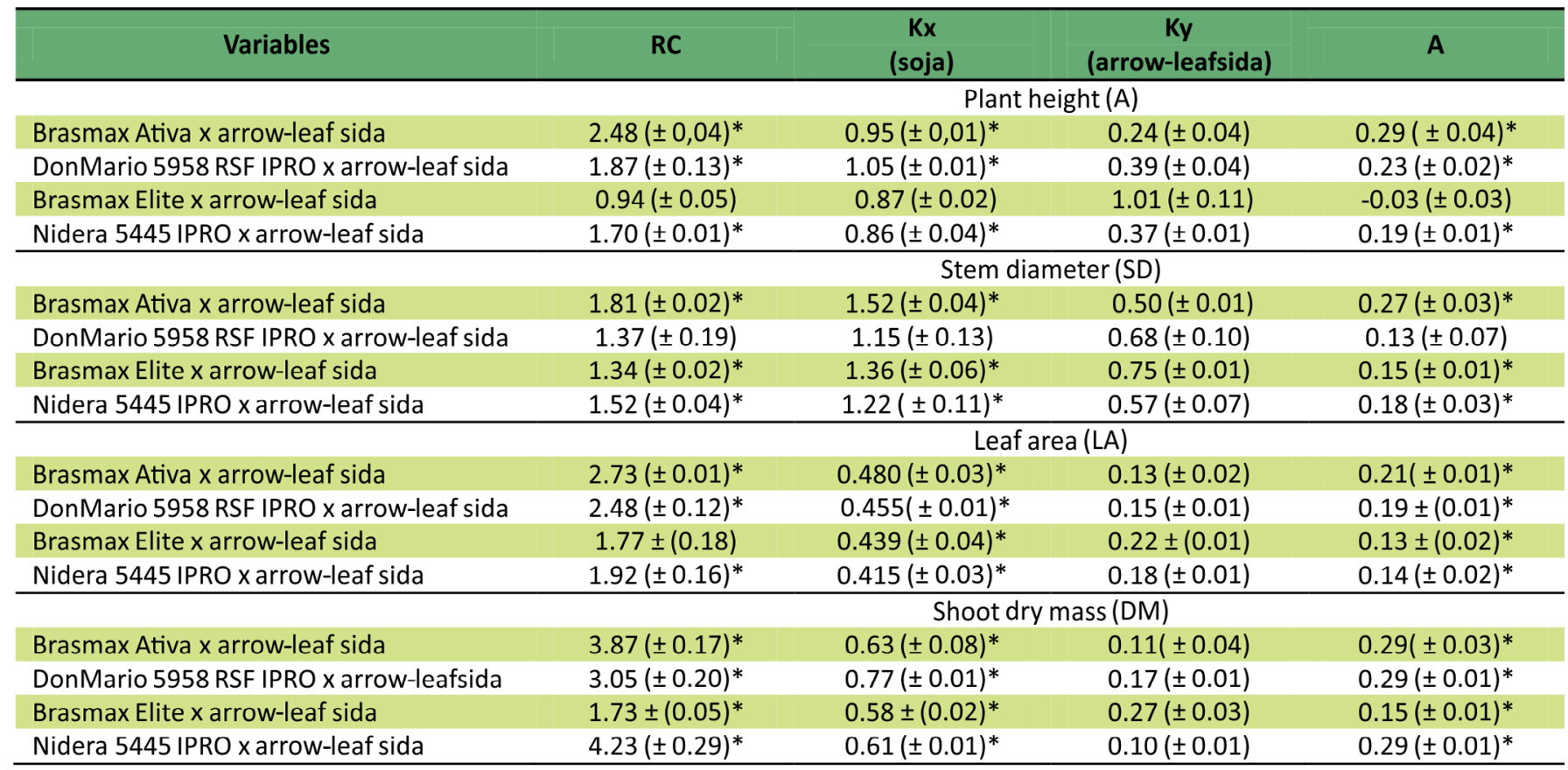

Significant difference by the $t$ test $(p<0.05)$. Values in parentheses represent the standard error of the average. $K_{x} A$ and $K_{y}$ are the relative clustering coefficients of soybean and arrow-leaf sida, respectively. 
aggressiveness index (positive A), the crop is more competitive than the weed. In all comparisons, significant differences were verified, except for the height and diameter of DonMario 5958 RSF IPRO plants, in which statistically significant differences did not occur in at least two tested proportions. This demonstrates that both species are not equal competitors for environmental resources, with soybeans being more competitive than arrowleaf sida. When soybeans competed with different species of Ipomoea spp., the crop stood out when compared to the weed, presenting greater efficiency in capturing environmental resources (Piccinini et al., 2016).

Using the three indexes to define competitiveness, it was verified that soybean was more competitive than red rice (Silva et al., 2014), beggarticks, wild poinsettia (Forte et al., 2017), and forage turnip (Bianchi et al., 2006). When evaluating the competitive ability of soybean infested by crabgrass, Agostinetto et al. (2013) also found that the crop was more competitive than the weed.

Thus, it can be concluded that differentiation exists regarding the three indices evaluated ( $R C, K$, and $A$ ): when soybean was cultivated with arrow-leaf sida, and only in two situations, there was no significant difference for the cultivar DonMario 5958 RSF IPRO in competition with arrow-leaf sida, in height and stem diameter for RC, K, and A indices (Table 2). The probable causes of this situation are cultivar characteristics such as an indeterminate growth habit, shorter cycle, mediumsized plants, lower leaf area index, and lowersoil fertility requirement, among other aspects. Regarding the three indices evaluated to define competitiveness, it was verified that soybean was more competitive than turnip (Bianchi et al., 2006), crabgrass (Agostinetto et al., 2013), or beggarticks and wild poinsettia (Forte et al., 2017).

In most situations, the crop presented greater competitive ability than the weed in isolation. This occurs because the effect caused by a weed species is not due to its individual competition but mainly to the combined effect of its total plant density (Bianchi et al., 2006). However, in some studies, weeds showed greater competitive ability, for example, when turnip infested soybean (Bianchi et al., 2006) or in Alexander grass and tropical spiderwort $x$ soybean (Dias et al., 2010).

Furthermore, in a plant community, the first established plants have an advantage when competing for resources, and there are benefits regarding the intrinsic characteristics of each cultivar in terms of competitive ability (height, growth speed, number of tillers, leaf area, dry mass, and others). Thus, lower amounts of resources will be available in the environment, which increases the damage caused to the competitor or crop (Agostinetto et al., 2013).

Interpretation of the graphical analysis of relative variables and their significance in relation to equivalent values (Figures 1-4), the morphological variables (Table 1), and the competitiveness indices (Table 2 ) revealed a negative interaction effect between the species, with soybean cultivars Brasmax Ativa, DonMario 5958 RSF IPRO, Brasmax Elite and Nidera 5445 IPRO and arrow-leaf sida being negatively affected. Soybean cultivars demonstrated greater competitive ability than arrow-leaf sida in all proportions of associated plants. Thus, the differences in competitiveness of the evaluated species may be due to their exploitation of the same resources, water, light, and nutrients in the environment.

\section{Conclusions}

Competition occurs between soybean cultivars (Brasmax Ativa, DonMario 5958 RSF IPRO, Brasmax Elite, and Nidera 5445 IPRO) and arrow-leaf sida, with plants being negatively affected with decreasedheight, diameter, leaf area, and shoot dry mass.

Interspecific competition causes greater damage to height, diameter, leaf area and dry mass of shoots than intraspecific competition.

Soybean and arrow-leaf compete for the same resources in the environment.

\section{Acknowledgements}

To the National Council for Scientific and Technological Development (CNPq), to the Research Support Foundation of the State of Rio Grande (FAPERGS), to the Federal University of Fronteira Sul (UFFS) and to the Funding Authority for Studies and Projects (FINEP), for the financial support for this research and for the Scientific Initiation and Postgraduate grants.

\section{Compliance with Ethical Standards}

Author contributions: Conceptualization: AK, LG, HVLP; Data curation: AK; SNW, LG; Formal analysis: LG, LB; Funding acquisition: LG; Investigation: $A K, L G, D B$; Methodology: $A L, L G, I A$; Project administration: LG, AK; Resources: LG, HVLP; Supervision: AG, LG, IA; Validation: AK, LG, IG, HVLP; Visualization: LRA, AG, IA; Writing - original draft: AG, IG, AK; Writing - review \& editing: AK, LG, AG, IA.

Conflict of interest: All authors declare that there are no personal or professional conflicts of interest.

Funding: National Council for Scientific and Technological Development - CNPq (Process number: 406221/2016-2 and 306927/2019-5), Research Support Foundation of the State of Rio Grande - FAPERGS (Process number: 17/2551-00002318 ) and Funding Authority for Studies and Projects - FINEP (Process number - 0752/13)

\section{Literature Cited}

Agostinetto, D.; Fontana, L.C.; Vargas, L.; Markus, C.; Oliveira, E. Relative competitive ability of crabgrass in coexistence with flooded rice and soybean. Pesquisa Agropecuária Brasileira, v.48, n.10, p.1315-1322, 2013. https://doi.org/10.1590/S0100204X2013001000002.

Bastiani, M.O.; Lamego, F.P.; Agostinetto, D.; Langaro, A.C.; Silva, D.C. Relative competitiveness of soybean cultivars with barnyardgrass. Bragantia, v.75, n.4, p.435-445, 2016. https://doi. org/10.1590/1678-4499.412. 
Bianchi, M.A.; Fleck, N.G.; Lamego, F.P. Proportion among soybean and competitor plants and the relationsof mutual interference. Ciência Rural, v.36, n.5, p.1380-1387, 2006. https://doi. org/10.1590/S0103-84782006000500006.

Concenço, G.; Andres, A.; Schreiber, F.; Scherner, A.; Behenck, J.P. Statistical approaches in weed research: choosing wisely. Revista Brasileira de Herbicidas, v.17, n.1, p.45-58, 2018. https://doi. org/10.7824/rbh.v17i1.536.

Constantin, J.; Oliveira Jr., R.S.; Kajihara, L.H.; Arantes, J.G.Z.; Cavalieri, S.D.; Alonso, D.G. 2007. Control of different species of Sida spp. with sequential applications of flumiclorac-pentil. Acta Scientiarum Agronomy, v.29, n.4, p.475-480, 2007. https://doi. org/10.4025/actasciagron.v29i4.403.

Cousens, R. Aspects of the design and interpretation of competition (interference) experiments. Weed Technology, v.5, n.3, p.664673, 1991. https://doi.org/10.1017/S0890037X00027524.

Cousens, R.; O'Neill, M. Density dependence of replacement series experiments. Oikos, v.66, n.2, p.347-352, 1993. https://doi. org/10.2307/3544824.

Cunha, V.C.; Santos, J.B.; Ferreira, E.A.; Cabral, C.M.; Silva, D.V.; Gandini, E.M. Comparative leaf anatomy of guanxuma species. Planta Daninha, v.30, n.2, p.341-349, 2012. https://doi. org/10.1590/S0100-83582013000200011.

Dias, A.C.R.; Carvalho, S.J.P.; Marcolini, L.W.; Melo, M.S.C.; Christoffoleti, P.J. Competitiveness of alexandergrass or bengal dayflower with soybean. Planta Daninha, v.28, n.3, p.515-522, 2010. https://doi.org/10.1590/S0100-83582010000300008.

Dusabumuremyi, P.; Niyibigira, C.; Mashingaidze, A.B. Narrow row planting increases yield and suppresses weeds in common bean (Phaseolus vulgaris L.) in a semi-arid agro-ecology of Nyagatare, Rwanda. Crop Protection, v.64, n.1, p.13-18, 2014. https://doi. org/10.1016/j.cropro.2014.05.021.

Empresa Brasileira de Pesquisa Agropecuária - Embrapa. Sistema brasileiro de classificação de solos. 1.ed. Brasília: Embrapa Solos, 2013.154 p.

Fleck, N.G.; Agostinetto, D.; Galon, L.; Schaedler, C.E.; 2008.Relative competitivity among flooded rice cultivars and a red rice biotype. Planta Daninha, v.26, n.1, p.101-111, 2008. https://doi. org/10.1590/S0100-83582008000100011.

Forte, C.T.; Basso, F.J.M.; Galon, L.; Agazzi, L.R.; Nonemacher, F.; Concenço, G. Competitive ability of transgenic soybean cultivars coexisting with weeds. Revista Brasileira de Ciências Agrárias, v.12, n.2, p.185-193, 2017. https://doi.org/10.5039/agraria.v12i2a5444.

Franco, J.J.; Agostinetto, D.; Langaro, A.C.; Perboni, L.T.; Vargas, L. Relative competitiveness of goosegrass biotypes and soybean crops. Revista Caatinga, v.30, n.2, p.271-277, 2017. https://doi. org/10.1590/1983-21252017v30n201rc.

Frandoloso, F.; Galon, L.; Gabiatti, R.L.; Bianchessi, F.; Holz, C.M.; Menegat, A.D.; Santin, C.O.; Reichert Jr., F.W.; Franceschetti, M.B.; Bagnara, M.A.M.; Agazzi.L.R.; Forte C.T. Competition of maize hybrids with alexandergrass ('Urochloa plantaginea'). Australian Journal of Crop Science, v.13, n.9, p.1447-1455, 2019. https://doi.org/10.21475/ajcs.19.13.09.p1540.
Galon, L.; Agazzi, L.; Vargas, L.; Nonemacher, F.; Basso, F.J.M.; Perin, G.F.; Fernandes, F.; Forte, C.; Rocha, A.; Trevisol, R.; Winter, F. Competitive ability of canola hybrids with weeds. Planta Daninha, v.33, n.3, p.413-423, 2015b. https://doi.org/10.1590/ S0100-83582015000300004.

Galon, L.; Concenco, G.; Perin, G.F.; Silva, A.F.; Forte, C.T.; David, F.A.; Radüz, L.L.; Radünz, A.L.; Andres, A.; Tironi, S.P.; Concenço, S.E. Comparison of experimental methods to assess the competitive ability of weed species. American Journal of Plant Sciences, v.6. n.13, p.2185-2196, 2015a. https://doi.org/10.4236/ ajps.2015.613221.

Heap, I. Global perspective of herbicide resistant weeds. Pest Management Science, v.70, n.9, p.1306-1315, 2014. https://doi. org/10.1002/ps.3696.

Piccinini, F.; Martin, T.N.; Machado, S.L.O.; Kruse, N.D.; Schmatz, R, Soybeans competitiveness with morning glory. Planta Daninha, v.34, n.1, p.25-33, 2016. https://doi.org/10.1590/s010083582016340100003.

Rizzardi, M. A.; Fleck, N.G.; Mundstock, C.M.; Bianchi, M A. Perdas de rendimento de grãos de soja causadas por interferência de picãopreto e guanxuma. Ciência Rural, v. 33, n.4, p. 621-627, 2003. https://doi.org/10.1590/S0103-84782003000400005.

Rizzardi, M.A.; Silva, L. Manejo de plantas daninhas eudicotiledôneas na cultura da soja Roundup Ready. Planta Daninha, v.32, n.4, p.683-697, 2014. https://doi.org/10.1590/S010083582014000400003.

Rede Oficial de Análise de Solo e de Tecido Vegetal - ROLAS. Manual de adubação e calagem para os estados do Rio Grande do Sul e Santa Catarina. 10.ed. Porto Alegre: Sociedade Brasileira de Ciência do Solo, 2016. 376 p.

Rubin, R.S.; Langaro, A.C.; Mariani, F.; Agostinetto, D.; Berto, R.M. Relative competitive ability of irrigated rice with red rice susceptible or resistant to the herbicide imazapyr + imazapic. Arquivos do Instituto Biológico, v.81, n.2, p.173-179, 2014. https://doi.org/10.1590/1808-1657001242012.

Ruchel, Q.; Agostinetto, D.; Zandoná, R.R.; Ulguim, A.R.; Avila Neto, R.C.; Fraga, D.S. Competitive ability of soybean crop with C3 and C4 weeds. International Journal of Science and Research, v.5, n.5, p. 669-683, 2019. https://ijaer.in/2019files/ijaer_05_54.pdf. 02 Aug. 2020.

Silva, D.R.O.; Agostinetto, D.; Vargas, L.; Langaro, A.C.; Duarte, T.V. Competitive ability, secondary metabolism changes and cellular damage in soybean competing with Conyza bonariensis glyphosate-resistant and susceptible to glyphosate. Planta Daninha, v.32, n.3, p.579-589, 2014. https://doi.org/10.1590/ S0100-83582014000300014.

USDA, 2020

United States Department of Agriculture - USDA. Foreign Agricultural Service. World soybean production, consumption, and stocks. https://apps.fas.usda.gov/psdonline/app/index.html\#/. 09 Dec. 2020. 